DOI: $10.31866 / 2410-1915.20 .2019 .172400$

УДК 719:351.853-047.32

\title{
СУЧАСНИЙ СТАН ДЕРЖАВНОЇ РЕЄСТРАЦІЇ УКРАЇНСЬКИХ НЕРУХОМИХ ОБ’ЄКТІВ КУЛЬТУРНОЇ СПАДЩИНИ
}

\section{Зараховський Олександр Євгенович}

Кандидат культурології, ORCID: 0000-0003-4263-7870,zarakhovskyi@gmail.com, Київський національний університет культури і мистецтв, вул. Є. Коновальия, 36, Київ, Україна, 01133

Мета роботи: дослідити сучасний стан реєстрації та обліку нерухомих об’єктів культурної спадщини нашої держави. Методологія дослідження полягає у історичному аналізі хронології створення пам'яткоохоронних списків в Україні; також використовувалися методи огляду, систематизації та порівняння реєстрів пам'яток. Наукова новизна полягає у виявленні сучасного стану державної реєстрації нерухомих об'єктів культурної спадщини України. Висновки. Встановлено, що нині не існує повного, загального та офіційного реєстру нерухомих об'єктів культурної спадщини України, що суттєво ускладнює процеси дослідження, збереження, популяризації, використання об’єктів культурної спадщини в туристичній діяльності. Державний реєстр нерухомих пам'яток України - головний офіційний список українських об’єктів культурної спадщини - є неповним та незавершеним; залучення історико-культурних об’єктів до реєстру досить часто залежить від зміни політикоідеологічної системи. Нині найповнішим реєстром нерухомих об'єктів культурної спадщини України є єдиний публічний електронний реєстр історико-культурних пам’яток України, створений Громадською організацією «Вікімедіа Україна».

Ключові слова: культурна спадщина; пам’ятка; пам'яткоохоронні списки; охорона пам’яток.

\section{Вступ}

Під час аналізу, класифікації та використанні в туризмі об'єктів культурної спадщини певної місцевості, регіону чи всієї держави велике значення мають пам'яткоохоронні списки та реєстри. Виявлення, дослідження, занесення в спеціальні списки, реєстрація та збереження це основа не лише пам'яткоохоронної, але й туристичної діяльності. Незважаючи на велику кількість наукових публікацій, туристичних каталогів та карт присвячених історико-культурним об'єктам України, нині не існує повного, загального та офіційного списку (реєстру) пам'яток країни. Історія державної реєстрації українських історико-культурних об'єктів в радянський період та частково в період незалежної України розглянуті в дослідженні В.Бадяка. Проблемам створення повного загального реєстру пам’яток історії та культури держави присвячена

(c) Зараховський О. Є., 2019 
праця В. Горбика та Г. Денисенко. Сучасний стан збереження нерухомої культурної спадщини України висвітлений в дослідженні С. Кота. Проте, сучасні тенденції та проблеми державної реєстрації українських історикокультурних пам’яток майже не висвітлені в науковій літературі.

\section{Мета статті}

Метою дослідження є виявлення сучасного стану державної реєстрації нерухомих об’єктів культурної спадщини України. Завданнями, через які досягається мета дослідження, $є$ : аналіз основних історичних етапів розвитку пам'яткоохоронних списків в Україні; виявлення особливостей та проблем державної реєстрації українських історико-культурних пам’яток на сучасному етапі.

\section{Виклад матеріалу дослідження}

Історія державної реєстрації українських об’єктів культурної спадщини складається 3 декількох етапів. Перші спроби такої реєстрації були здійснені ще за часів Російської імперії. У XVIII ст. починають 3'являтися укази, в яких зазначався перелік предметів старовини, що представляють суспільний інтерес і лише в нормативно-правових актах XIX ст. фігурують нерухомі об'єкти культурної спадщини, а саме: архітектурні пам'ятки (Михайлова, 2002, с. 21).

У загальному наказі Міністерства внутрішніх справ громадським губернаторам від 3 червня 1837 р. зазначена вимога «о сбережении, по возможности, от разрушения всех остатков старых замков, крепостей и других памятников древности». Наприкінці XIX - поч. XX ст. з'являються нормативно-правові документи, що визначають необхідність та регламентують процес збирання статистичної інформації про нерухомі пам'ятки історії та культури Російської імперії. У цих документах зазначаються такі поняття, як «пам'ятники старовини», «старовинні пам'ятники» та «історичні пам'ятники». Серед таких документів «Циркуляр Министерства внутренних дел о привлечении губернских и областных статистических комитетов к участию в сборе сведений о памятниках древности» від 27 квітня 1863 р., «Положение об охране древних памятников» від 21 березня 1869 р. та «Докладная записка о подготовке Проекта правил о сохранении исторических памятников» від 20 квітня 1877 р. (Михайлова, 2002, с. 22).

Завдяки пам'яткоохоронній діяльності розвивалась і розширювалась сама класифікація нерухомих пам'яток історії та культури. У 1869 р. було запропоновано розподіляти пам'ятники архітектури на споруди: кам'яні та дерев’яні; та всі штучні насипи: вали, городища, кургани. У 1905 р. 3-поміж нерухомих об'єктів спадщини виокремилися монументи на честь видатних осіб та історичних подій (Михайлова, 2002, с. 23).

Позитивною рисою вищезазначених документів Російської імперії $\epsilon$ виведення проблеми реєстрації та збереження об’єктів культурної 
спадщини на загальнодержавних рівень, перші спроби класифікації пам'яток старовини та збір даних про них. Недоліком залишалася відсутність повних списків величезної кількості пам’яток історії та культури, розкиданих по території імперії. Потреба в загальних списках, куди б заносилися нерухомі об'єкти культурної спадщини, що потребують охорони та відновлення, виникла з поваленням монархії та неконтрольованим нищенням всієї культурної спадщини попереднього політичного режиму.

Радянський період ознаменував появу перших в Україні нормативноправових документів, що регламентували порядок виявлення, реєстрації та збереження рухомих (музейних) та нерухомих об'єктів культурної спадщини. Серед таких документів першим було «Положення про пам'ятники культури й природи» прийняте ВУЦВК і РНК УРСР 16 червня 1926 р. На основі цього документу було створено загальний список зареєстрованих нерухомих об’єктів культурної спадщини. Серед найважливіших нормативно-правових актів щодо реєстрації нерухомих об’єктів культурної спадщини у радянській Україні можна виділити постанови «Про організацію Комітету охорони та збереження історикокультурних, архітектурних і археологічних пам’яток УРСР» (1940 р.), «Про заходи до впорядкування стану пам'ятників культури, старовини і природи на території УРСР» (1945 р.) та Закон УРСР «Про охорону і використання пам’яток історії та культури» (1978 р.) (Бадяк, 2013, с. 351, 354).

Після розпаду СРСР знову постало питання переобліку об'єктів культурної спадщини, зміни ціннісних критеріїв щодо їх включення в список. У 1992 р. Верховна Рада України прийняла «Основи законодавства України про культуру», згідно з якими виникла необхідність складання Державного реєстру української культурної спадщини. У статті 14 закону сказано, що «до культурних цінностей належать об'єкти матеріальної і духовної культури, що мають художнє, історичне, етнографічне та наукове значення. Унікальні цінності матеріальної та духовної культури, а також культурні цінності, що мають виняткове історичне значення для формування національної самосвідомості українського народу, визнаються об'єктами національного культурного надбання і заносяться до Державного реєстру національного культурного надбання». У 1999 р. до Держреєстру було включено 3541 пам'ятку архітектури та 602 пам’ятки інших типів (Бадяк, 2013, с. 357).

У 2000 р. було прийнято Закон «Про охорону культурної спадщини». у цьому нормативно-правовому акті подано широку класифікацію нерухомих об’єктів культурної спадщини за типами (споруди, комплекси й визначні місця), за видами (археологічні, історичні, монументального мистецтва, ландшафтні та садово-паркового мистецтва), за категоріями (національного і місцевого значення). Робота, пов'язана 3 пам'ятками національного значення, покладалася на Кабінет Міністрів, місцевого - на місцеві органи влади. При розробці цього закону керувалися міжнародним досвідом законодавства в сфері охорони та збереження культурної спадщини. Він досить наближений до Конвенції ЮНЕСКО «Про охорону 
всесвітньої культурної і природної спадщини» від 1972 р. Позитивною рисою Закону є новація, введена зі змінами 2004 року, згідно з якою об’єкти науки і техніки виділені окремим видом пам'яток (Бадяк, 2013, с. 358).

Згідно з цим законом список, в який вносяться об'єкти культурної спадщини, отримав назву «Державного реєстру нерухомих пам'яток України», який є чинним і нині. Об'єкти культурної спадщини, що вносяться в Державний реєстр нерухомих пам'яток України, офіційно беруться під охорону держави та набувають статусу пам'яток. Нині це офіційний список об’єктів культурної спадщини України, який замінив Державний реєстр національного культурного надбання, що існував до 2000 року (Закон України «Про охорону культурної спадщини», 2000).

27 грудня 2001 р. була прийнята Постанова «Про затвердження Порядку визначення категорій пам’яток для занесення об'єктів культурної спадщини до Державного реєстру нерухомих пам'яток України». Порядок визначав, що включення об’єкту до Держреєстру відбувається лише за наявності відповідної облікової документації (облікової картки, паспорту, короткої історичної довідки, акту технічного стану, довідки про майнову цінність об’єкта). Для включення у список пам’яток національного значення об’єкт має відповідати критерію автентичності (пам'ятка повинна значною мірою зберегти свою форму та матеріально-технічну структуру, історичні нашарування, а також роль у навколишньому середовищі), а також хоча одному з наступних критеріїв:

- значний вплив на розвиток культури, архітектури, містобудування, мистецтва країни;

- безпосередньо пов'язані з історичними подіями, віруваннями, життям і діяльністю видатних людей;

- репрезентують шедевр творчого генія, стали етапними творами видатних архітекторів чи інших митців;

- були витворами зниклої цивілізації чи мистецького стилю.

Для пам'яток місцевого значення критерії наступні:

- вплинули на розвиток культури, архітектури, містобудування, мистецтва певного населеного пункту чи регіону;

- пов'язані з історичними подіями, віруваннями, життям і діяльністю видатних людей певного населеного пункту чи регіону;

- $є$ творами відомих архітекторів або інших митців;

- $\epsilon$ культурною спадщиною національної меншини чи регіональної етнічної групи (Постанова «Про затвердження Порядку визначення категорій пам’яток для занесення об’єктів культурної спадщини до Державного реєстру нерухомих пам’яток України», 2001).

у 2001 р. у Держреєстр пам'яток національного значення було внесено: 140 історичних, 44 монументальних і 415 археологічних об’єктів. Проблемою залишалася неповнота Держреєстру, так як не було затверджено список пам'яток архітектури та містобудування. Станом на початок 2002 р. загальна кількість пам'яток у Державному реєстрі нерухомих пам'яток України становила 129709: 125566 місцевого та 4143 національного значення. Не зважаючи на таку суттєву кількість об’єктів, список повністю 
не відображав українську культурну спадщину. Велика кількість пам'яток, занесених до реєстру, продовжувала вшановувати комуністичних лідерів та події, наслідки яких, здебільшого, були негативними для української самосвідомості та незалежності. Зокрема, Хмельницька область 3474 пам'ятників містила 291, що вшановувала Леніна та інших комуністичних діячів. Подібна ситуація в більшості областей, особливо південно-східного регіону України. Зрозуміло, що переважна більшість цих об’єктів не має високої мистецької та естетичної цінності (Бадяк, 2013, c. 359).

У 2008 р. зі списку було виключено 2578 об’єктів культурної спадщини, пов'язаної 3 комуністичним минулим країни. Суттєвим недоліком Держреєстру була не так його нестабільність, постійні зміни і корективи, як те, що часто ці зміни не публічні та невідомі широкому загалу (Бадяк, 2013, с. 359-360).

3 вересня 2009 р. була прийнята Постанова «Про занесення об’єктів культурної спадщини національного значення до Державного реєстру нерухомих пам'яток України». Цей документ скасовував більш ранні постанови 1965-го, 1996-го і 2001-го років. У новому Держреєстрі значилося 625 пам'яток (161 історичних, 34 монументального мистецтва, 417 археології та 13 змішаного типу) (Бадяк, 2013, с. 360).

Перевагою чинного Державного реєстру нерухомих пам'яток України $\epsilon$ структурна побудова за географічним принципом, тобто реєстрація та занесення до списку об'єктів культурної спадщини за областями, районами та населеними пунктами. Це суттєво полегшує аналіз концентрації пам'яток та туристичної привабливості певного регіону або населеного пункту. Але, як зазначають дослідники, і він має ряд недоліків. По-перше, у списку відсутній ряд поховань відомих українських постатей: співака А. Солов'яненка в с. Козині на Київщині; патріарха Київського і всієї РусиУкраїни Володимира (Романюка) на Софіївській площі Києва; художника Й. Бокшая (м. Ужгород); ученого В. Гнатюка; олімпійського чемпіона, гімнаста В. Чукаріна; композитора В. Івасюка; художника М. Бідняка; багатьох поховань визначних українців на Личаківському цвинтарі. Що ж до останнього - цей некрополь, що є музеєм-заповідником, представлений у списку досить неповним переліком могил, хоча статус зобов'язує охороняти всі об’єкти на його території (Бадяк, 2013, с. 360-361).

По-друге, нинішній Держреєстр заносить деякі об'єкти в помилкові категорії. Наприклад, Монумент на честь надання Києву Магдебурзького права, що є, по суті, пам’яткою монументального мистецтва, занесений в список як пам'ятка історії. До категорії мистецьких пам'яток занесено церкву 1886 р. в селі Мацошин (Львівська обл.), а в археологічні половецькі кам'яні скульптури. По-третє, в списку нерухомих пам'яток $\epsilon$ плутанина щодо статусів: пам'ятнику Івану Франку в м. Львів надано статус національного, в той час як пам'ятний знак на честь засновників Києва, монумент Незалежності і пам’ятник Сагайдачному цього статусу не мають. До того ж в списку пам'яток місцевого значення є багато об’єктів, що за своєю мистецькою, історичною чи науковою цінністю не поступаються 
багатьом об’єктам національного рангу. Серед інших прикладів недоліків Держреєстру - могила художника М. Федюка у Винниках (Львівщина), яка не занесена в список, в той час як хата, в котрій він мешкав, в ньому значиться. Також у м. Хуст (Закарпаття) охороняється таблиця на будівлі (пам'ятка історії), де засідав сейм Карпатської України, а не сама будівля (Бадяк, 2013, с. 361).

Певні зміни у Держреєстрі відбулися 3 прийняттям 9 квітня 2015 р. Закону України «Про засудження комуністичного та націоналсоціалістичного (нацистського) тоталітарних режимів в Україні та заборону пропаганди їхньої символіки». Згідно з цим законом під поняття комуністичної символіки підпадає ряд об'єктів культурної спадщини, зокрема пам'ятки, що вже включені до Держреєстру. У першій статті Закону зазначено, що символіка комуністичного режиму маає «зображення, пам'ятники, пам'ятні знаки, написи, присвячені особам, які обіймали керівні посади в комуністичній партії (посаду секретаря районного комітету і вище), особам, які обіймали керівні посади у вищих органах влади та управління СРСР, УРСР (УСРР), інших союзних або автономних радянських республік, органах влади та управління областей, міст республіканського підпорядкування, працівникам радянських органів державної безпеки всіх рівнів», а також «присвячені подіям, пов’язаним 3 діяльністю комуністичної партії, із встановленням радянської влади на території України або в окремих адміністративно-територіальних одиницях, переслідуванням учасників боротьби за незалежність України у XX ст. (крім пам'ятників та пам'ятних знаків, пов'язаних 3 опором і вигнанням нацистських окупантів з України або з розвитком української науки та культури)» (Закон України «Про засудження комуністичного та націонал-соціалістичного (нацистського) тоталітарних режимів в Україні та заборону пропаганди їхньої символіки», 2015).

На виконання приписів Закону Міністерство культури видало Наказ від 26 листопада 2015 р. «Про незанесення об’єктів культурної спадщини до Державного реєстру нерухомих пам'яток України». Згідно Наказу 3 Держреєстру виключено 41 пам'ятку: 40 пам'ятників В.Леніну та 1 пам'ятник борцям за Радянську владу на західноукраїнських землях. Ці об’єкти розташовані у Донецькій (м. Слов’янськ - 1), Рівненській (с. Гоща - 1), Харківській (с. Мечебилове - 1), Хмельницькій (м. Ізяслав - 1), Чернігівській (36) областях та в Запоріжжі (1) (Наказ Міністерства культури України «Про незанесення об’єктів культурної спадщини до Державного реєстру нерухомих пам'яток України», 2015). Нині ці об’єкти не мають статусу пам'яток та офіційно не знаходяться під охороною держави. Можна спрогнозувати, що це лише початок зменшення кількості пам’яток радянського часу у Держреєстрі.

Питання про правильність видання вищезазначеного наказу є дискусійним. 3 одного боку, «декомунізаційний» пакет законів сприятиме «очищенню» Держрреєстру від величезної кількості одноманітних, низькопробних (в мистецькому сенсі) монументів, що значилися лише завдяки пануючій ідеології. 3 іншого - він може стати засобом політичної 
боротьби одного режиму проти іншого, коли зі списку виключаються пам'ятки історії та культури, що мають історичну, мистецьку, або іншу цінність, але суперечать ідеологічним засадам сучасної політичної системи. Протилежна, але подібна ситуація була в період приходу більшовиків до влади, коли зі списку масово виключалися об’єкти сакральної архітектури, руйнувалися церкви, монастирі. Культурна спадщина радянського часу $\epsilon$ невід’ємною частиною культурного надбання сучасної України і вона обов'язково має бути представлена у Держреєстрі.

Крім нестабільності кількості пам’яток, Держреєстр має більш суттєвий недолік - неповнота списку. Списки пам'яток місцевого та національного значення відкриті для широкого загалу на офіційному сайті Міністерства культури України, подані в абетковому порядку за областями. Але вони висвітлюють лише незначну частину усієї кількості нерухомих об'єктів культурної спадщини, що мають статус пам’яток. Наприклад, у списку пам'яток Черкаської області зазначено 40 пам'яток національного та лише 45 місцевого значення (Державний реєстр нерухомих пам'яток України).

Як зазначають дослідники (Бадяк, 2013, с. 364-365), державна реєстрація та класифікація українських об’єктів культурної спадщини досі незавершена і має певні проблеми. Серед найголовніших недоліків чинного Держреєстру, крім неповноти списків, $є$ те, що:

- пам’ятки архітектури та містобудування залишаються поза увагою Уряду;

- об'єкти садово-паркового мистецтва та ландшафтні пам'ятки не вписані в єдиний блок спадщини;

- не викликають належної зацікавленості та уваги пам'ятки науки і техніки.

Проте, збором даних про пам'ятки історії й культури та їхнім зведенням в єдиний реєстр займаються не тільки державні органи влади, а й громадські організації. Громадською організацією «Вікі-медіа Україна», що співпрацює з Українським товариством охорони пам'яток історії і культури, було створено єдиний публічний реєстр пам'яток культурної спадщини України, що налічує 41466 пам'яток. Список формувався на основі даних в Державному реєстрі нерухомих пам'яток України, а також в офіційних реєстрах пам'яток обласних та районних державних адміністрацій. Кожен запис реєстру містить назву пам'ятки, державний номер реєстрації, номер і дату рішення про включення до реєстру, адресу розташування, унікальний 9-значний ідентифікатор, з яких 5 знаків - код із класифікатора об’єктів адміністративно-територіального устрою України і 4 знаки - код пам'ятки чи комплексу пам'яток. Для 5827 пам'яток реєстр містить також точну географічну довготу і широту. Поки що, електронний список історико-культурних пам'яток, створений «Вікімедіа Україна» $\epsilon$ найповнішим реєстром нерухомих об'єктів культурної спадщини України. До прикладу, згідно з ним, на території Черкаської області розташовано 1547 історико-культурних пам'яток, серед яких 77 національного і 1470 місцевого значення (Списки пам’яток Wikimedia, 2017). 
Міністерство культури України мало в планах запровадити офіційний електронний реєстр нерухомих історичних пам'яток України на державному рівні. Такий реєстр мав спростити процедуру внесення до списку, та дозволити ефективно захищати нерухомі об'єкти культурної спадщини. Також, згідно з законом «Про декомунізацію», це б спростило процедуру вилучення 3 реєстрів пам'яток комуністичного режиму та комуністичної пропаганди. Даний реєстр міг би стати потужною інформаційною базою для пам'яткок, які матимуть інформацію про дату заснування, адресу, стан, документацію щодо проекту будівлі, а також передумовою до створення Центру документації пам’яток. Але й нині цей проект залишається нереалізованим.

\section{Висновки}

Встановлено, що Державний реєстр нерухомих пам'яток України головний офіційний список українських об’єктів культурної спадщини $\epsilon$ неповним та незавершеним: до нього входить незначна частина об’єктів культурної спадщини нашої держави; залучення нерухомих об’єктів культурної спадщини до реєстру досить часто залежить від зміни політико-ідеологічної системи. Нині не існує повного, загального та офіційного реєстру нерухомих об’єктів культурної спадщини України, що суттєво ускладнює процеси дослідження, збереження, популяризації, використання об'єктів культурної спадщини в туристичній діяльності. Найповнішим реєстром нерухомих об’єктів культурної спадщини України $\epsilon$ єдиний публічний електронний реєстр історико-культурних пам'яток України, створений Громадською організацією «Вікімедіа Україна». Науково-методологічні проблеми створення єдиного повного державного реєстру нерухомих об’єктів культурної спадщини України, з урахуванням досвіду пам’яткоохоронної діяльності недержавних організацій, можуть бути предметом подальших наукових досліджень.

\section{Список використаних джерел}

1. Бадяк В. До питання реєстрації об’єктів культурної спадщини України з позицій фаховості та національної гідності. Вісник Львівської національної академії мистецтв. Львів, 2013. № 24. С. 348-367.

2. Державний реєстр нерухомих пам'яток України. URL: http://mincult.kmu. gov.ua/control/uk/publish/officialcategory?cat_id=244910406 (дата звернення: 10.06.2019).

3. Закон України Про охорону культурної спадщини : прийнятий 8 черв. 2000 року №39. Відомості Верховної Ради України. 2000. Ст. 333.

4. Закон України Про засудження комуністичного та націоналсоціалістичного (нацистського) тоталітарних режимів в Україні та заборону пропаганди їхньої символіки : прийнятий 9 квіт. 2015 року № 26. Відомості Верховної Ради України. 2015. Ст. 219. 
5. Михайлова Н. В. Государственно-правовая охрана историко-культурного наследия России во второй половине XX в. : дис. ... д-ра юрид. наук /Юридический институт МВД России. Москва, 2002. 370 с.

6. Наказ Міністерства Культури України Про незанесення об’єктів культурної спадщини до Державного реєстру нерухомих пам'яток України : виданий 26 листопада 2015 року № 977. URL : http://mincult.kmu.gov.ua/control/uk/publish/ article?art_id=245094337\&cat_id=244950594 (дата звернення: 10.06.2019).

7. Постанова Кабінету Міністрів України Про затвердження Порядку визначення категорій пам'яток для занесення об'єктів культурної спадщини до Державного реєстру нерухомих пам’яток України : прийнята 27 груд. 2001 року № 1760. Офіційний вісник України. 2001. Ст. 2372.

8. Списки пам'яток громадської організації «Вікімедіа Україна». URL: http:// wikilovesmonuments.org.ua/lists (дата звернення: 10.06.2019).

\section{References}

Badiak, V. (2013). Do pytannia reiestratsii obiektiv kulturnoi spadshchyny Ukrainy z pozytsii fakhovosti ta natsionalnoi hidnosti [On the issue of registration of objects of cultural heritage of Ukraine from the standpoint of professionalism and national dignity]. Visnyk Lvivskoi natsionalnoi akademii mystetstv, no. 24, pp. 348-367.

Derzhavnyi reiestr nerukhomykh pamiatok Ukrainy [State Register of Real Property Monuments of Ukraine]. (n.d.). [online] Available at: <http://mincult.kmu.gov.ua/ control/uk/publish/officialcategory?cat_id=244910406> [Accessed: 10 June 2019].

Mikhailova, N.V. (2002). Gosudarstvenno-pravovaya okhrana istoriko-kul'turnogo naslediya Rossii vo vtoroi polovine $X X v$. [State legal protection of the historical and cultural heritage of Russia in the latter half of the 20th century]. DEd. Law Institute of the Ministry of Internal Affairs of Russia.

Nakaz Ministerstva Kultury Ukrainy Pro nezanesennia obiektiv kulturnoi spadshchyny do Derzhavnoho reiestru nerukhomykh pamiatok Ukrainy: vydanyi 26 lystopada 2015 roku № 977. [Order of the Ministry of Culture of Ukraine on the noncommissioning of cultural heritage objects to the State Register of real estate monuments of Ukraine from November 26 2015, no. 977], [online] Available at: $<$ http://mincult.kmu.gov.ua/control/uk/publish/article?art_id=245094337 \&cat_ $\mathrm{id}=244950594>$ [Accessed: 10 June 2019].

Postanova Kabinetu Ministriv Ukrainy Pro zatverdzhennia Poriadku vyznachennia katehorii pamiatok dlia zanesennia obiektiv kulturnoi spadshchyny do Derzhavnoho reiestru nerukhomykh pamiatok Ukrainy: pryiniata 27 hrud. 2001 roku № 1760 [Resolution of the Cabinet of Ministers of Ukraine on approval of the procedure for the definition of the categories of sites for the inclusion of cultural heritage objects in the state register of immovable monuments of Ukraine from December 272001, № 1760]. (2001, December 27). Ofitsiinyi visnyk Ukrainy. P. 2372.

Spysky pamiatok hromadskoi orhanizatsii "Vikimedia Ukraina" [Lists of sites of public organization “Wikimedia Ukraine”], [online] Available at: <http://wikilovesmonuments. org.ua/lists> [Accessed: 10 June 2019].

Zakon Ukrainy Pro okhoronu kulturnoi spadshchyny : pryiniatyi 8 cherv. 2000 roku №39 [Law of Ukraine on the protection of cultural heritage from June 8 2000, no. 39] 
(2000, June 8). Vidomosti Verkhovnoi Rady Ukrainy. Kyiv: Parlamentske vydavnytstvo. P. 333.

Zakon Ukrainy Pro zasudzhennia komunistychnoho ta natsional-sotsialistychnoho (natsystskoho) totalitarnykh rezhymiv $\mathrm{v}$ Ukraini ta zaboronu propahandy yikhnoi symvoliky : pryiniatyi 9 kvit. 2015 roku № 26 [Law of Ukraine on conviction of communist and national-socialist (nazi) totalitarian regimes in Ukraine and the prohibition of the promotion of their symbols from April 9 2015, no. 26] (2015, April 9). Vidomosti Verkhovnoi Rady Ukrainy. Kyiv : Parlamentske vydavnytstvo. P. 219.

\section{STATE REGISTER OF UKRAINIAN CULTURAL HERITAGE REAL PROPERTY AS IT STANDS}

\section{Oleksandr Zarakhovskyi}

PhD in Cultural Studies, ORCID: 0000-0003-4263-7870,zarakhovskyi@gmail.com, Kyiv National University of Culture and Arts, Kyiv, Ukraine

The aim of the study is to investigate the current state of registration and list of cultural heritage real property of our country. The methodology of the research consists in a historical analysis of the chronology of the lists of protected monuments in Ukraine; methods of reviewing, systematizing and comparing the registers of monuments were also used. The scientific novelty consists in revealing the real condition of the state registration of cultural heritage real property of Ukraine. Conclusions. It is established that today there is no complete, general and official register of cultural heritage real property of Ukraine, which considerably complicates the processes of research, preservation, popularization and use of objects of cultural heritage in tourism. State register of real estate monuments of Ukraine the main official list of Ukrainian cultural heritage objects - is incomplete and unfinished; including historical and cultural objects on the register often depends on the change of the political and ideological system. Currently, the most comprehensive register of cultural heritage real property of Ukraine is the only public electronic register of historical and cultural monuments of Ukraine, created by the Public organization "Wikimedia Ukraine".

Keywords: cultural heritage; a memorial; memorial lists; protection of monuments. 


\title{
СОВРЕМЕННОЕ СОСТОЯНИЕ ГОСУДАРСТВЕННОЙ РЕГИСТРАЦИИ УКРАИНСКИХ НЕДВИЖИМЫХ ОБЪЕКТОВ КУЛЬТУРНОГО НАСЛЕДИЯ
}

\author{
Зараховский Александр Евгеньевич
}

Кандидат культурологии, ORCID: 0000-0003-4263-7870,zarakhovskyi@gmail.com, Киевский национальный университет культуры и искусств, Киев, Украина

Цель статьи: исследовать современное состояние регистрации и учета недвижимых объектов культурного наследия нашего государства. Методология исследования заключается в историческом анализе хронологии создания охраны памятников списков в Украине; также использовались методы осмотра, систематизации и сравнения реестров памятников. Научная новизна заключается в выявлении современного состояния государственной регистрации недвижимых объектов культурного наследия Украины. Выводы. Установлено, что в настоящее время не существует полного, общего и официальный реестр недвижимых объектов культурного наследия Украины, что существенно усложняет процессы исследования, сохранения, популяризации, использования объектов культурного наследия в туристической деятельности. Государственный реестр недвижимых памятников Украины - главный официальный список украинских объектов культурного наследия является неполным и незавершенным; привлечение историко-культурных объектов в реестр достаточно часто зависит от изменения политико-идеологической системы. Сейчас полным реестром недвижимых объектов культурного наследия Украины есть единственный публичный электронный реестр историко-культурных памятников Украины, созданный Общественной организацией «Викимедиа Украина».

Ключевые слова: культурное наследие; достопримечательность; памятникоохранные списки; охрана памятников. 